ヒト膀胼腫瘍継代培養細胞に打ける細胞間

$$
\begin{aligned}
& \text { コミュニケーションの検討 } \\
& \text { 東京医科歯科大学医学部泌尿器科学教室 } \\
& \text { 木原 和徳 影山 幸雄* 寿美 周平 } \\
& \text { 東四雄福井巌大島 博幸 }
\end{aligned}
$$

\title{
A STUDY OF INTERCELLULAR COMMUNICATION OF HUMAN TRANSITIONAL CELL CARCINOMA CELL LINES
}

\author{
Kazunori Kihara, Yukio Kageyama, Shuhei Sumi, Yotsuo Higashi, \\ Iwao Fukui and Hiroyuki Oshima \\ Department of Urology, School of Medicine, Tokyo Medical and Dental University
}

Intercellular communication (IC) was investigated by a dye transfer method in 5 human bladder carcinoma cell lines, JTC-29, JTC-30, JTC-32, HUB-41 and T-24 which showed various histological anaplasia when transplanted into nude mice. IC was investigated as follows; 1 ) IC among cells of each bladder carcinoma cell lines, 2) IC between various combination of different cell lines and 3) IC between cells of bladder carcinoma cell lines and fibroblasts prepared from the human skin or prostate. High IC was observed among JTC-30 cells which showed a differentiated pattern when transplanted into nude mice. JTC-32 and HUB-41, of which transplanted tumors showed poorly differenciated patterns, demonstrated lower IC than JTC-30. Statistical significance was present only between JTC30 and JTC-32 cells $(\mathrm{p}<0.05)$. T-24 which formed histologically anaplastic tumor in nude mice demonstrated markedly poor IC. Second, IC between two different cell lines was demonstrated only between JTC-30 and JTC-32. Third, fibroblass from the skin and prostate had high IC but showed apparent IC with none of bladder carcinoma cell lines. These findings indicate that ICs of bladder tumor cells vary with cell lines tested and appear to decrease with progress of malignant anaplasia. Furthermore, the fact that there is sometimes high IC and sometimes lack of IC between differenciated and undifferenciated tumor cells suggests a possible role of IC in prevention of malignant progression. The present study provides no evidence of IC between bladder tumor cells and fibroblasts, which in some reports have been suggested to be an important phenomenon in evaluating the metastatic capacity of cancer cells.

\footnotetext{
要旨：ヌードマウス移植における形態で異なる分化度を示す 5 種のヒト膀椫腫湟形代培養細胞を対象と して, 蛍光色素注入法を用いて細胞間コミュニケーション (IC) の検討を行なった。 IC は次の項目につ いて検討した．1）各膀脂腫瘍培養細胞自身のIC．2）異なる膀腅腫瘍培養細胞同士の IC．3）膀腅腫瘍 培養細胞とヒト皮虐および前立腺由来線維芽細胞とのIC、ヌードマウス移植にて中等度分化型を示す JTC-30の IC は良好であり, 低分化型を示す JTC-32と HUB-41の ICはJTC-30より低かった. しかしな がら有意の差は，JTC-30と JTC-32 との間でのみ認められた $(\mathrm{p}<0.05)$. 移植にて未分化型を示す T-24 の IC は著明に低下していた. 分化度の異なる膀胖腫瘍細胞同士の IC は JTC-30と JTC-32との間で認め られ，他の組合せではIC の存在は明らかではなかった。線維芽細胞はそれ自身は良好な IC を持ってい るにもかかわらず, いずれの膀胱腫瘍細胞とも明らかな IC を示さなかった. 以上の結果より膀胱腫瘍細 胞は正常膀羘上皮とは異なる多様な IC を持っている可能性が高く, 特に IC の著明に低下している腫瘍
}

\footnotetext{
* 現 埼玉医科大学泌尿器科
} 
細胞は悪性度が高いことが想定された。さらに分化度の異なる膀胖腫瘍細胞間にも様々な IC の存在が 予想され，これが腫瘍の grade upに関与している可能性も想定された。 また癌細胞と間質細胞との IC の有無と転移性との関連も示唆されているが，今回の検討では膀腅腫瘍細胞と線維芽細胞との間には明 らかなICは認められなかった。

\section{緒言}

細胞間コミュニケーションは, 細胞間接着部の ギャップ結合を介する，低分子物質の直接の移動によ る細胞相互の情報伝達システムであり, 生体内のほと んどの組織にみられ，細胞の分化，増殖に重要な役割 を果たしていると考えられている11.つまり，細胞の内 部はギャップ結合部にある多数の小孔を通して直接, 隣接する細胞の内部と連絡して扣り，分子量 1,000 〜 1,500以下の物質すなわち, $\mathrm{Na}^{+}, \mathrm{K}^{+}$等のイオンや nucleotideなどは自由に細胞間を往来することができ る. 最近, この細胞間コミュニケーションの変化が発 癌や癌の悪性進展に深く関与していると考兄られるよ らになってきて扣り，この説を支持する多くの事実が 見い出されてきている2) 9). 今回われわれは, 膀胱腫煌 細胞を用いて, 分化度の変化に伴う細胞間コミュニ ケーションの変化, 分化度の異なる膀胱腫瘍細胞同士 のコミュニケーションの有無, 間質細胞とのコミュニ ケーションの有無について検討した.

\section{対象}

膀胱腫瘍細胞として, JTC-29, JTC-30, JTC-32, HUB-41，T-24の 5 種の継代培養細胞を用いた。 JTC29, JTC-30, JTC-32, HUB-41は教室の患者より樹立 された細胞であり, JTC-32は低分化型, 他の 3 種は中 等度分化型の移行上皮癌に由来している.また T-24は 1973年, Bubenik ら ${ }^{10}$ により grade 3の膀胱癌から樹 立された細胞である。これらの細胞を継代早期にヌー ドマウスへ移植した際の形態は, JTC-30が分化型, JTC-29, JTC-32, HUB-41が低分化型を示した ${ }^{11)}$. 各 継代培養細胞の in vivo での形態に関しては, 細胞間 コミュニケーション測定時に改めてヌードマウスへの 移植を行ない検討した。間質細胞として, 手術時に採 取したヒトの皮膚および前立腺の組織片より培養した 線維芽細胞を用いた。

\section{方 法}

i ）細胞培養

培養液として DM- $170+13 \% \mathrm{FCS}$ を用い, $37^{\circ} \mathrm{C}$, $5 \% \mathrm{CO}_{2}$ 気相下にインキュベーター内で培養した。培 地の交換は 3 日もしくは 4 日毎に行なった.

ii）細胞間コミュニケーションの測定 dye transfer 法を用いた ${ }^{12)}$ 。これは蛍光色素を 1 個 の細胞に注入し, 色素の隣接細胞への拡がりを測定す る方法であり, 細胞間コミュニケーションを蛍光色素 の拡がった細胞数で評価するものである，蛍光色素と して Lucifer yellow $\mathrm{CH}$ (分子量450）を用いたが，こ の色素は細胞膜を通過して細胞内へ入ることはないの で，その隣接細胞への移動はギャップ結合を介した直 接の移動と考えられる. Lucifer yellow $\mathrm{CH}$ は，0.33 M lithium chrolide 液で溶解し，10\%（W/V) 溶液と して用いた。色素の細胞内注入にはオリンパス製イン ジェクトスコープ（IMT-2-SYF）を用い，注入に使用 したガラス針はナリシゲ製微小電極製作器（PN-3）に て作製した. 各腫瘍細胞のコミュニケーションの測定 は，約 $5 \times 10^{5}$ 個の細胞を小さな cluster としてディッ シュに播き，10日間培養した後に行なった。 2 つの異 なる細胞群間のコミュニケーションの測定には，まず 一方の細胞を小さな cluster としてディッシュに播き (約 $5 \times 10^{5}$ 個), 4 日間培養後, 細胞集団が島状に形成 された所で, 他方の細胞を cluster もしくは single cell として同数混入し，さらに 4 日間培養して両細胞群の 接触した状態を作製した。次いで両細胞群の接触部位 に扔いて一方の細胞群の 1 個の細胞に蛍光色素を注入 し, 他方の細胞群への色素の移動の有無を観察した。 2 種の細胞群はその形態にて識別可能であった。

iii）膀胱腫場継代培養細胞の in vitoにおける組織 像

細胞間コミュニケーションの測定と同時に各膀腅腫 瘍細胞の一部 $\left(5 \times 10^{6}\right.$ 個 $)$ をードマウスに移植し, 形 成された腫瘍を 1 カ月後に摘出し，その組織像を検討 した。

\section{結 果}

i ）膀胼腫瑒継代培盖細胞のヌードマウス移植にお ける組織像

JTC-30は中等度分化型の組織構築を示し, JTC-29, JTC-32, HUB-41は低分化型の像を呈し，T-24は極め て末分化な形態を示した（Fig. 2C).

ii）膀胱腫瘍継代培養細胞の細胞間コミュニケー ション (Fig. 1)

ヌードマウス移植にて, 最も高い分化度を示す 
Fig. 1 Intercellular communication of bladder carcinoma cell lines. Each point represents the mean of 26-34 separated injections. Bars indicate S.D.

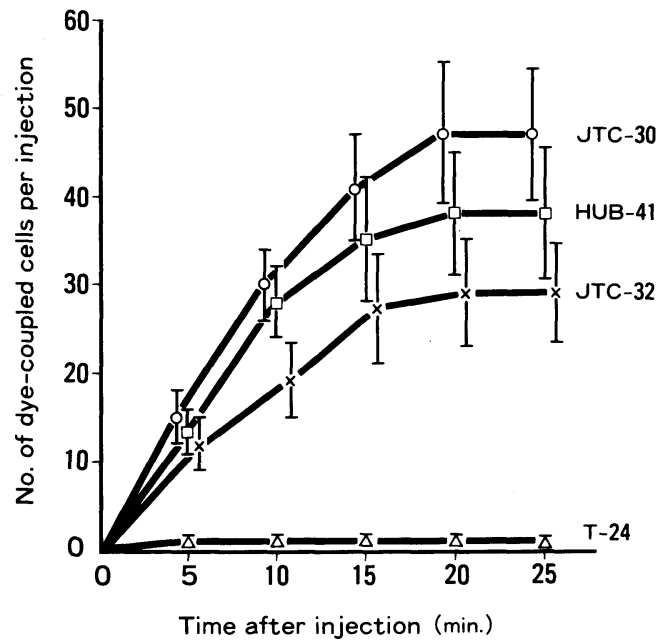

JTC-30が, 最も良好なコミュニケーションを示した。 マイクロインジェクション後, 色素は 5 分で約 15 個の 隣接細胞に拡がり, 経時的にその数は増加し, 約 20 分 でプラトーに達し, 平均47個の細胞に拡がった。この プラトーの状態は20分以上維持された (Fig. 2A, 2B). ヌードマウス移植にて低分化型を示すJTC-32 と HUB-41では, 色素注入後の細胞間コミュニケーショ ンの経時的変化は JTC-30 と類似であったが，その值 はJTC-30より低い傾向を示した (Fig. 2A, 2B). プラ トーの状態で, JTC-30と HUB-41とのコミュニケー ションには有意の差はなかったが, JTC-30と JTC-32 との間には危険率 $5 \%$ で有意の差が認められた。一方, ヌードマウス移植にて極めて未分化な形態を示す T. 24では, コミュニケーションは色素注入後20分以上経 過しても，ないかあるいは $2 〜 3$ 個程度であった(Fig. 2A, 2B). なお, JTC-29は半浮遊状の細胞であり, デ イッシュ底面に付着する細胞集団の構成細胞数が少な く, dye transfer 法ではコミュニケーションの測定が 必ずしも正確ではないため本検討から除外した。

iii）分化度の異なる膀胱腫瘍細胞間のコミュニケー ション (Table 1)

JTC-30は JTC-32との間に良好なコミュニケーショ ンを示した (Fig. 3)。しかしながら他の組合せでは明 らかなコミュニケーションを示さなかった. JTC-29, HUB-41，T-24では他のいずれの細胞との間にも明瞭
なコミュニケーションはなかった(Fig. 3)。T-24はそ れ自身のコミュニケーション能が極めて低いため, 他 の細胞とのコミュニケーションが欠如しているとも考 えられるが, HUB-41, JTC-29はそれ自身コミュニ ケーションがあるにもかかわらず，他の膀胱腫瘍細胞 との間に良好なコミュニケーションは認められなかっ た.

iv）膀胱腫瘍細胞と間質細胞とのコミュニケーショ (Table 1)

前立腺由来の線維芽細胞，皮䖉由来の線維芽細胞の いずれもそれ自身は良好な細胞間コミュニケーション を示したが，これらの間質細胞は JTC-29，JTC-30, JTC-32, HUB-41, T-24のいづれの膀胱腫瘍細胞とも 明らかなコミュニケーションを示さなかった（Fig. $3)$.

\section{考察}

細胞間コミュニケーションを担っているギャップ結 合部の微綢構造は電顕的にみると, Fig. 4 の様であ り，6個のサブュニットからなるコネクソン分子が筒 状に形質膜を貫き，隣りのコネクンン分子と結合して いる。この筒の内径は約 $20 \AA$ であり，この小孔が隣接 細胞内腔を直接連絡している，正常の膀脱上皮細胞に は良好なコミュニケーションがあることは知られてい るが，今回検討したヒト膀胱腫瘍細胞では，コミュニ ケーションの良好な細胞から極度に低下した細胞ま で，多様なコミュニケーションが認められた。腫瘍細 胞では正常細胞に比し，コミュニケーションが低下し

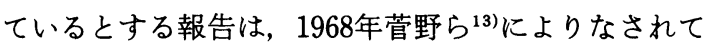
おり，彼らは肝や胃の癌組織においてこの現象を観察 している.しかしながら逆に培養系では, 良好なコミュ ニケーション能を持つ癌細胞も少なからずあることも 知られてきている。つまり癌細胞であるからといって 必ずしもコミュニケーション能が低下しているとは言 えないが,コミュニケーションの著明に低下した癌細 胞は，分化度の低い，悪性度の高い癌細胞であろうと 考えられている，今回の膀胼腫瘍細胞における検討で も，この考えに一致する結果が得られた。すなわち， ヌードマウス移植にて，高い分化度を示すJTC-30は 最も良好なコミュニケーションを持ち，未分化な形態 を示す T-24はコミュニケーション能が極端に低下し て㧍りこれらの中間の形態を示す JTC-32は JTC-30 より低いコミュニケーションを示した。 この継代培養 細胞における結果からみて, in vivo の膀胖腫煌細胞で も，そのコミュニケーションの程度には多様な幅があ 
Fig. 2 Pattern of dye transfer and histology of bladder carcinoma cell lines. (A) Phase contrast photomicrograph. Magnification, $300 \times$. (B) Fluorescence photomicrograph of (A). Single cell was injected with lucifer yellow $\mathrm{CH}(\star)$ and photographed 20 minute later. (C) Histology when transplanted into nude mice. Magnification, $100 \times$

A
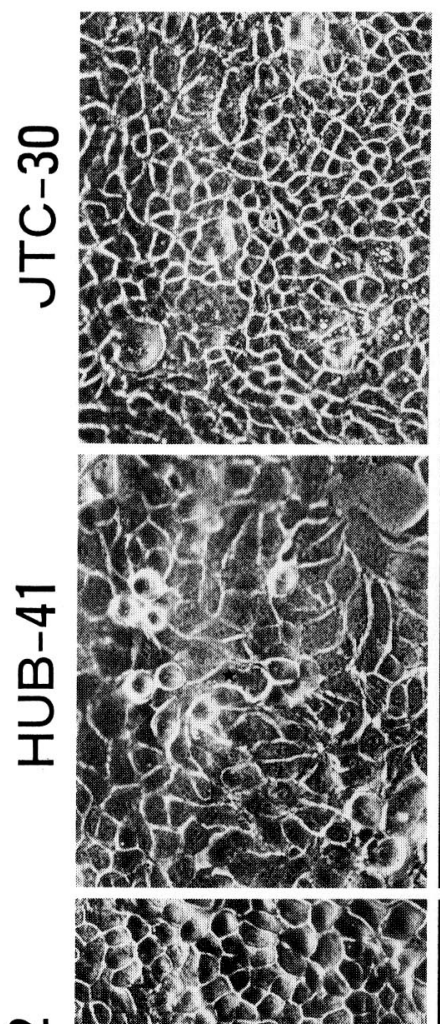

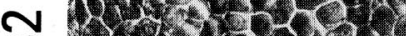

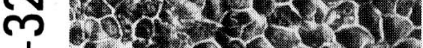

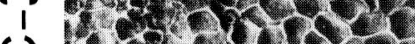

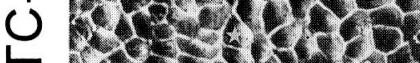
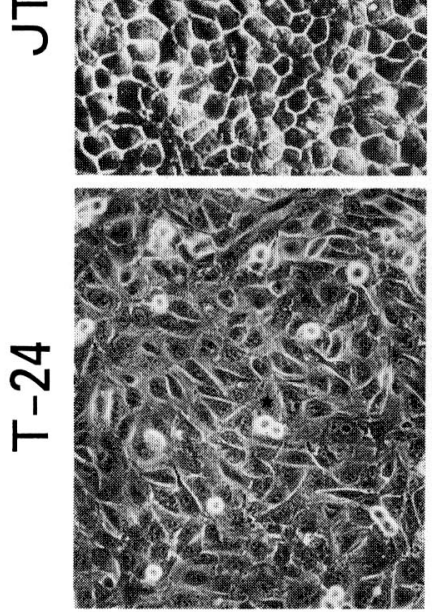

B
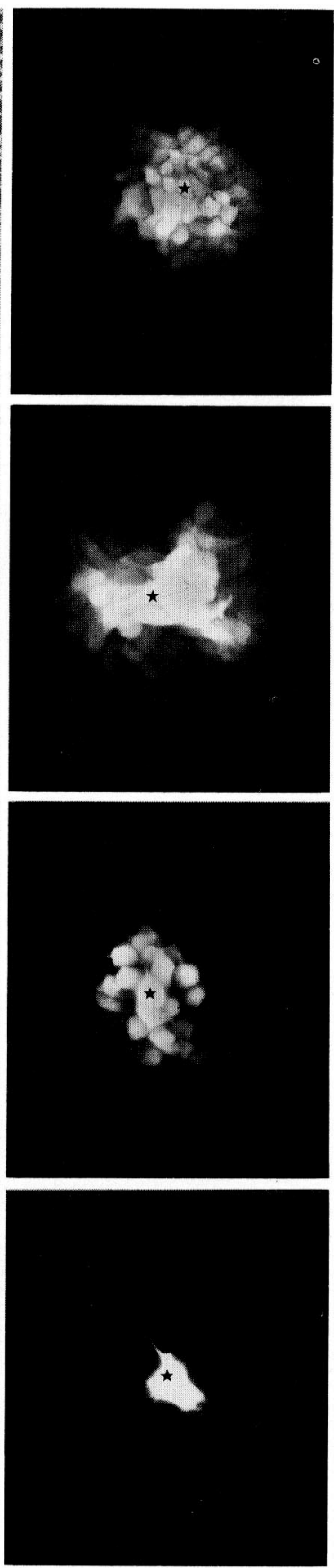

C

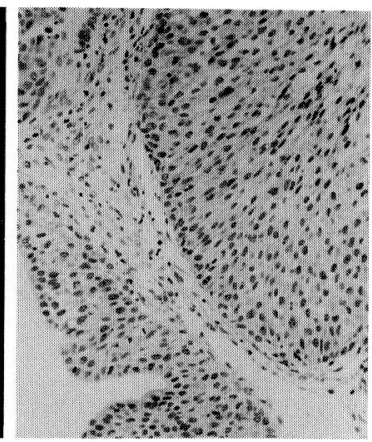

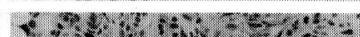

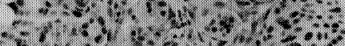

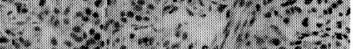

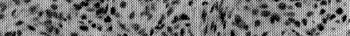

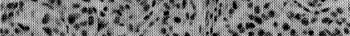

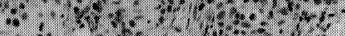

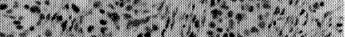

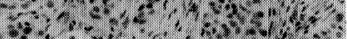

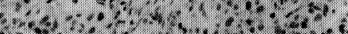

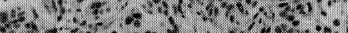

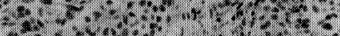

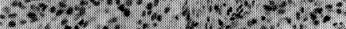

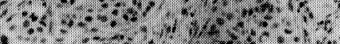

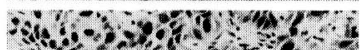

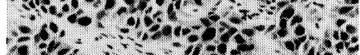

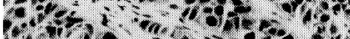

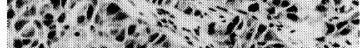
$78=8$ \%

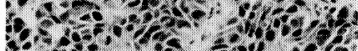

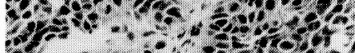

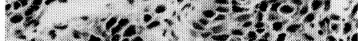

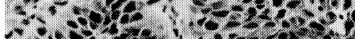

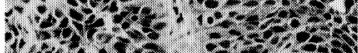

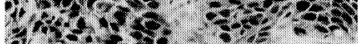
3 sosest-2, $\because \overline{0}$

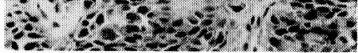
\%"W-27.

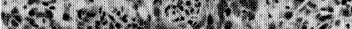

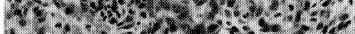

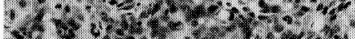

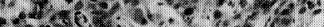

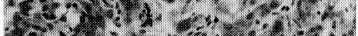

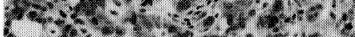

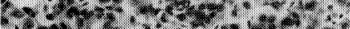

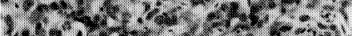

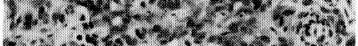
5.7.

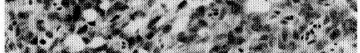

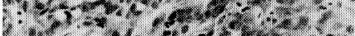

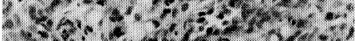

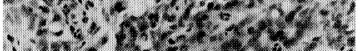


Fig. 3 Intercellular communication (IC) between various combination of different bladder carcinoma cell lines and IC between bladder carcinoma cells and fibroblasts.

(A) Phase contrast photomicrograph. Magnification, $300 \times$. (B) Fluoresence photomicrograph of (A). Single cell was injected with lucifer yellow $\mathrm{CH}(\star)$ and photographed 20 minutes later.

\section{A}

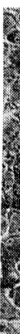

JTC-30

(lower)

$$
\underset{\text { (upper) }}{+}
$$

JTC-29 (upper)

$+$

JTC-30

(lower)

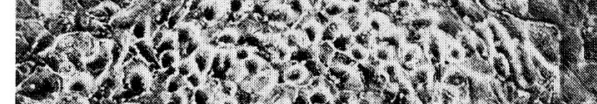

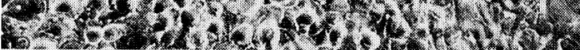

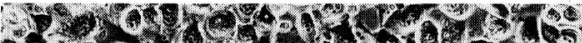

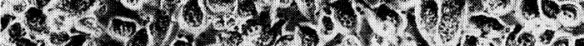
310 .

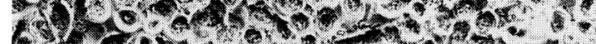

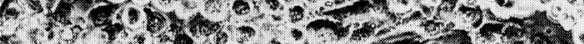

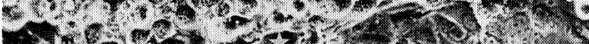

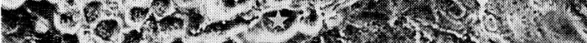

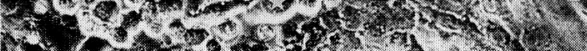

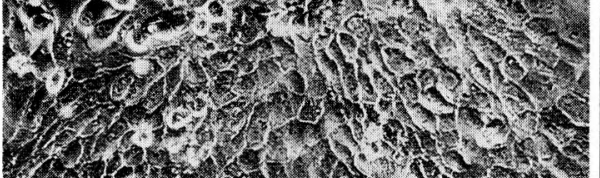

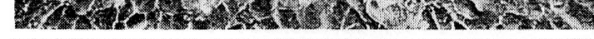

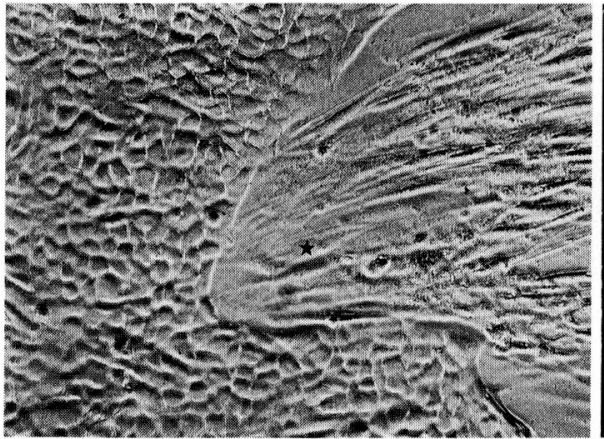

JTC-30

(1eft)

$+$

Fibroblasts

(right)

JTC-32

( left)

$+$

Fibroblasts

(right)

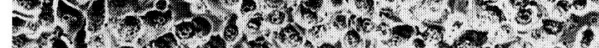
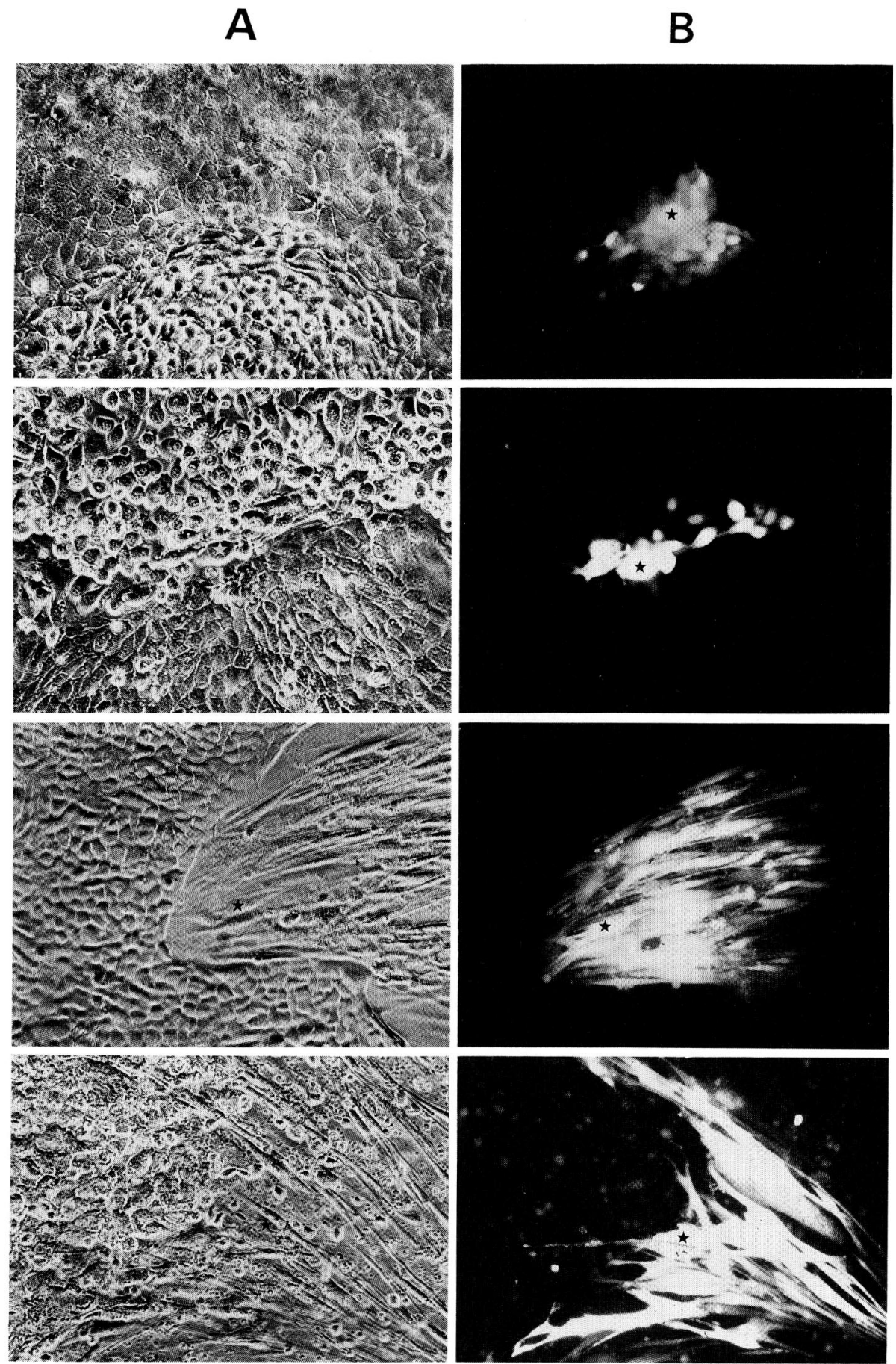
Table 1 Intercellular communication (IC) between two different TCC cell lines and IC between TCC cells and fibroblasts.

+ : IC observed. : - : IC was not observed.

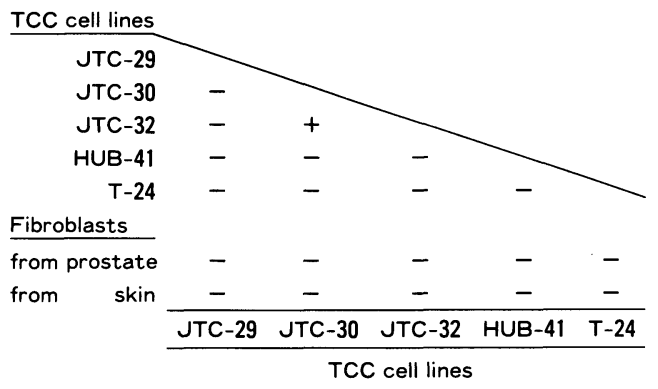

Fig. 4 Schema of the gap junction.

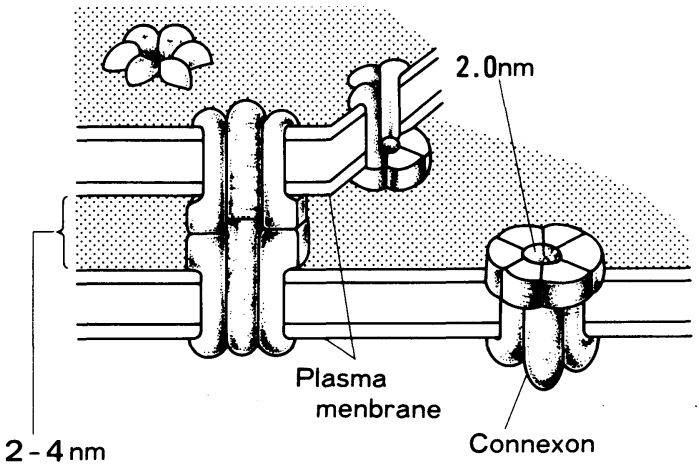

(by S. Yamashina, 1985)

り, 特に悪性度の高い癌細胞ではコミュニケーション 能が著明に低下している場合のあることが想定され た.

一方, 実際のヒトの膀胼腫瘍では 1 個の腫場塊の中 に悪性度の異なる細胞が混在していることも多い。こ れら悪性度の異なる細胞間でのコミュニケーションが どのようになっているかは興味深い問題である。発癌 の過程においては，イニシェーターにより遺伝子の変 異を生じた变異細胞は, 周囲の正常細胞とのコミュニ ケーションにより癌化が抑制されているが，プロモー ターによってこのコミュニケーションが絶たれると癌 細胞となり，腫場が形成されてくるとも考えられてい $3^{9{ }^{914}}$. この説はまた, 悪性度の異なる細胞の混在状態 においては, 悪性度の低い細胞が悪性度の高い細胞の 増殖に何らかの抑制的な働きかけをしている可能性も 示唆していると思われる。そこで悪性度の異なる膀胀
腫瘍細胞同士のコミュニケーションを検討したが，中 等度分化型腫瘍と低分化型腫瘍の組合せでも JTC-30 と JTC-32の様に相互のコミュニケーションの良い組 合せと, JTC-30とJTC-29の様に相互にはコミュニ ケーションのない組合せとがあり，さらにそれ自身コ ミュニケーション能の低い未分化型の T-24は予測さ れた通り，他のいかなる細胞ともコミュケーションが なかった。これらの結果は膀脱癌の grade up を研究す る場合には, 細胞間コミュニケーションの消長を考慮 に入れる必要があることを示唆している。

また腫湯の転移性とコミュニケーションとの関連に も興味が持たれており, 転移を生じやすい細胞と生じ にくい細胞とを比較して, 前者は間質細胞とのコミュ ニケーションがそしく，後者は良好であったとのラッ トの乳癌細胞での実験報告もある ${ }^{15)}$. しかし今回の検 討では, 間質細胞とコミュニケーションを持つ膀胱腫 場細胞はなく，間質との相互作用を示す所見は得られ なかった。

最近, 細胞間コミュニケーションの抑制を指標とし て，プロモーターを検出しようとする試みもなされて いるが，これは主として動物の間質細胞を用いて行な われている(16). しかしながら,プロモーターには種特異 性, 臓器特異性があることを考えると, ヒト膀胱腫場 のプロモーター検出にはヒトの膀胱上皮細胞を用いる ことが必要不可欠であり, 今回の検討で明らかとなっ た良好なコミュニケーションを持つヒト膀胱癌由来の 細胞株は, ヒト膀脱癌のプロモーターの検出にも応用 しうるであろうと考えられる。

\section{結 語}

ヌードマウス移植に抢ける形態で，異なる分化度を 示す 5 種のヒト膀胱腫場継代培養細胞を用いて, 各膀 胼腫瘍細胞自身のコミュニケーション, 異なる分化度 を示す細胞間でのコミュニケーションおよび間質細胞 とのコミュニケーションについて検討した。

1. 膀胱腫瘍細胞自身のコミュニケーションは, ヌー ドマウス移植にて最も高い分化度を示す JTC-30が最 良で, 未分化型を示す T-24はそのコミュニケーション が極度に低下しており，低分化型を示すJTC-32は JTC-30より低いコミュニーケーションを示した. 膀胱腫 瘍細胞は正常上皮細胞とは異なるコミュニケーション を持っている可能性が高く，かつその程度は多様であ り, 特にコミュニケーションが著明に低下している癌 細胞は悪性度が高いことが想定された。

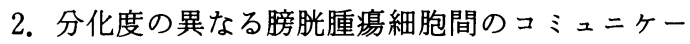


ションは, 欠如している組合せと, 良好な組合せとが 認められ, 種々の分化度の癌細胞が混在していること も多い in vivo での腫煬では, 各分化度の細胞集団間 に多様なコミュニケーションの存在が予想され, これ が癌細胞の grade up 関与している可能性も想定さ れた。

3. 膀胀腫瘍細胞は今回検索した限りでは, いずれも 間質細胞とはコミュニケーションを持たず, 間質細胞 とのコミュニヶーションを介した相互作用は今回の検 討では認められなかった。

稿を終えるにあたり, 東京医科歯科大学写真室の高田正 雄氏ならびに本研究に協力して下さった当科研究室の太田 聖子氏に感謝致します。

本論文の要旨の一部は第75回日本泌尿器科学会総会にて 発表した。

本研究は文部省科学研究費 (一般研究 B, 61480339) に よった。

\section{文献}

1) Loewenstein, W.R.: Junctional intercellular communication and the control of growth. Biochim. Biophys. Acta, 560, 1-65, 1979.

2) Yotti, L.P., Chang, C.C. and Trosko, J.E.: Elimination of metabolic cooperation in chinese hamster cells by a tumor promoter. Science, 296, 1089-1091, 1979.

3) Fitzgerald, D.J. and Murray, A.W.: Inhibition of intercellular communication by tumorpromoting phorbol esters. Cancer Res., 40, 2935-2937, 1980.

4) Fitzgerald, D.J., Knowles, S.E., Ballard, F.J. and Murray, A.W.: Rapid and reversible inhibition of junctional communication by tumor promoters in a mouse cell line. Cancer Res., 43 , 3614-3618, 1983.

5) Enomoto, T. and Yamasaki, H.: Lack of intercellular communication between chemically transformed and surrounding nontransformed BALB/C 3T3 cells. Cancer Res., 44, 5200-5203, 1984.

6) Enomoto, T. and Yamasaki, H.: Phorbol ester-mediated inhibition of intercellular communication in BALB/C 3T3 cells : Relationship to enhancement of cell transformation. Cancer Res., 45, 2681-2688, 1985.

7) Rivedal, E., Sanner, T., Enomoto, T. and Yamasaki, H. : Inhibition of intercellular communication and enhancement of morphological transformation of Syrian hamster embryo cells by TPA. Use of TPA-sensitive and TPAresistant cell lines. Carcinogenesis, 6, 899-902, 1985.

8) Mahta, P.P., Bertram, J.S. and Loewenstein, W. R.: Growth inhibition of transformed cells correlates with their juctional communication with normal cells. Cell, 44, 187-196, 1986.

9) Trosko, J.E.: Mechanisms of tumor promotion: Possible role of inhibited intercellular communication. Eur. J. Cancer Clin. Oncol., 23, 599-601, 1987.

10) Bubenik, J., Baresova, M., Viklicky, V., Jaknoubkova, J., Sainerova, H. and Donner, H.: Established cell line of urinary bladder carcinoma (T-24) containing tumor-specific antigen. Int. J. Cancer, 11, 765-773, 1973.

11) Kakuya, T., Yamada, T., Yokokawa, M. and Ueda, T.: Establishment of cell strains from human urothelial carcinoma and their morphological characterization. In vitro, 19, 591 $-599,1983$.

12) Enomoto, T., Martel, M., Kanno, Y. and Yamasaki, H.: Inhibition of cell communication between BALB/C $3 \mathrm{~T} 3$ cells by tumor promoters and protection by cAMP. J. Cell Physiol., 121, 323-333, 1984.

13) Kanno, Y. and Matsui, Y.: Cellular uncoupling in cancerous stomach epithelium. Nature, 218, 775-776, 1968.

14) Yamasaki, H., Hollstein, M., Mesnil, M., Martel, N. and Aguelon, A.M.: Selective lack of intercellular communication between transformed and nontransformed cells as a common property of chemical and oncogene transformation of BALB/C $3 \mathrm{~T} 3$ cells. Cancer Res., 47, 5658-5664, 1987.

15) Hamada, J., Takeichi, N. and Kobayashi, H.: Inverse correlation between the metastatic capacity of cell clones derived from a rat mammary carcinoma and their intercellular communication with normal fibroblasts. JPN. J. Cancer Res., Gann, 78, 1175-1178, 1987.

16) Zeilmaker, M.J. and Yamasaki, H.: Inhibition of junctional intercellular communication as a possible short-term test to detect tumorpromoting agents: Results with nine chemicals tested by dye transfer assay in chinese hamster V79 cells. Cancer Res., 46, 6180-6186, 1986.

（1989年 1 月20日受理） 